\section{Volume 4 - Nomor $3 \cdot$ Juni 2021 \\ Pege (Hal.) : $302-316$}

(C) Universitas Pamulang

JL.Surya Kencana No.1 Pamulang, Tangerang Selatan - Banten

website. :

Telp. (021) 7412566, Fax (021)

7412491

http://www.openjournal.unpam.ac.id/index.php/JPK Email : jurnalmarketing.unpam@gmail.com

\title{
Rekomendasi Pedoman Komunikasi Pemasaran Berbasis Pertimbangan Etika Key Opinion Leaders Industri e-Commerce
}

\author{
Louise Angelita ${ }^{1}$. Andika Putra Pratama ${ }^{2}$ \\ louise angelita@sbm-itb.ac.id/louiseangelitakemur@gmail.com, andika.putra@sbm-itb.ac.id
}

\begin{abstract}
Abstrak: Dengan semakin bertumbuhnya penetrasi internet di Indonesia, ditambah dengan efek dari COVID-19 di tahun 2020 lalu, industri e-commerce menjadi bertumbuh pesat. Selain itu, pertumbuhan influencer juga menjadi salah satu strategi yang menjadi mulai dikenal dan diadopsi oleh beberapa perusahaan. Penggunaan influencer sebagai strategi pemasaran sering dikenal juga sebagai sebagai influencer marketing, yaitu penggunaan beberapa orang yang memiliki kemampuan untuk meningkatkan pengetahuan konsumen terhadap suatu brand. Sekelompok orang ini yang dikenal sebagai Key Opinion Leaders ini menjadi banyak juga digunakan, salah satunya di industri $e-$ commerce. Melalui penelitian ini, peneliti melakukan penelitian kualitatif dengan cara observasi terhadap salah satu perusahaan e-commerce selama 3.5 bulan secara langsung, melakukan wawancara mendalam terhadap 3 Key Opinion Leaders (KOL) dan 3 karyawan yang bekerja erat dengan para KOL, sehingga dapat memahami isu bisnis yang terjadi, lalu juga dapat menyusun strategi pemasaran dalam bentuk pedoman sebagai solusi isu yang terjadi dan mencegah adanya persoalan-persoalan etika di kemudian hari.
\end{abstract}

Keywords: Influencer Marketing; Key Opinion Leader; E-Commerce; Komunikasi Pemasaran; Etika Pemasaran; Word-of-Mouth; e-WOM

\begin{abstract}
With the growing internet penetration in Indonesia, followed by the effect of COVID-19 in 2020, the e-commerce industry is growing rapidly. In addition, the growth of influencers becomes one of the strategies that has become known and adopted, known as influencer marketing also used in e-commerce industry. The influencer marketing is the use of several people who have the ability to increase consumer awareness of a brand. This group of people, also known as Key Opinion Leaders. However, it is also found that the used of influencer gain new problems such as unethical conducts or unethical contents found in the platform. Through this study, qualitative research was done by observing an e-commerce company for 3.5 months and conducting in-depth interviews with 3 Key Opinion Leaders and 3 employees in the pursuit of compiling good procedures related to their marketing communication to solve the problem and prevent any ethical issues.
\end{abstract}

Keywords: Influencer Marketing; Key Opinion Leader; E-Commerce; Marketing Communication, Ethics in Marketing; e-WOM; Word of Mouth 


\section{A. PENDAHULUAN}

Pada tahun 2020, ditemukan bahwa penetrasi internet di Indonesia meningkat secara pesat, yaitu hingga $64 \%$ dari total 272,1 juta penduduk di Indonesia. Selain itu, seiring hal tersebut, pertumbuhan pada Industri e-commerce juga terus meningkat. Pada akhir tahun 2020, ditemukan bahwa industri e-commerce sudah memiliki sekitar 160 juta pengguna atau sekitar 59\% dari total populasi di Indonesia (Hootsuite, 2020). Hal ini merupakan sebuah peningkatan yang pesat jika dibandingkan dengan tahun sebelumnya.

Salah satu ahli di bidang e-commerce, CEO dari Sirclo, Brian Marshal, menyatakan bahwa peningkatan signifikan pada tahun 2020 bisa terjadi karena merupakan dampak dari pandemi COVID-19 pada tahun 2020. Hal ini terjadi karena pada saat pandemi COVID-19, beberapa peraturan membatasi orang-orang untuk berpergian dan beberapa tempat akhirnya harus ditutup. Dengan ditutupnya banyak toko offline dan pembatasan berpergian, berbelanja secara daring menjadi salah satu pilihan yang industri e-commerce menjadi pilihan bagi banyak masyarakat. Berdasarkan pernyataan dari CEO Sirclo, pandemi berkontribusi $91 \%$ terhadap pertumbuhan di industri e-commerce, terdapat sebanyak 12 juta pengguna baru di akhir tahun 2020 (Pernyataan oleh CEO Sirclo, Brion Marshal, ditulis di Techno, Nov 2020). Diestimasikan tingkat pertumbuhan industri e-commerce di Indonesia tahun 2021 sebesar 10,21\% (Statista, 2020).

Banyak pelaku bisnis kemudian menggunakan sebuah strategi yang juga dikenal sebagai Influencer Marketing untuk membujuk pengguna baru dalam menggunakan program aplikasi mereka dan untuk mengejar jumlah pesanan yang lebih tinggi dengan menggunakan jasa para influencer. Peneliti melakukan sebuah penelitian terhadap perusahaan X. Perusahan X menggunakan juga strategi influencer marketing, dengan cara influencer terpilih yang mewakili sebuah perusahaan $\mathrm{X}$ akan dikenal sebagai Key Opinion Leader (KOL) dan akan dibantu oleh suatu divisi tertentu yang mengurus para KOL ini.

Studi Nielsen Tapinfluence 2016 menunjukkan bahwa para influencer memiliki performa setidaknya 3 kali lebih baik daripada pemasaran tradisional (Tapinfluence Nielsen, 2016). Penelitian yang dilakukan pada tahun 2016 oleh Astuti juga menunjukkan bahwa influencer juga memberikan pengaruh yang cukup tinggi terhadap niat beli konsumen, yaitu sebesar 89,7\% (Astuti, R.L.M.B, 2016:7). Salah satu studi yang dilakukan APJII 2018 menunjukkan bahwa salah satu perusahaan e-commerce menggunakan influencer marketing untuk mendongkrak penjualan dan berhasil meningkatkan angka 3,22 persen (APJII, 2018 dalam Maulana, Manulang dan Salsabila, 2020:29).

Perusahaan $X$ yang akan menjadi objek penelitian yang juga menggunakan influencer sebagai salah satu strategi pemasarannya. Perusahaan $X$ menggunakan strategi ini dikarenakan dengan biaya yang lebih rendah dibandingkan strategi pemasaran yang lainnya, influencer mampu memberikan dampak yang cukup tinggi.

Namun, seiring dengan pertumbuhan internet, pertumbuhan industri e-commerce, dan penggunaan strategi pemasaran dengan para Key Opinion Leaders, peneliti juga menemukan bahwa terdapat beberapa persoalan-persoalan etika berkaitan dengan konten yang dibagikan. Isu ini berkaitan dengan sisi etika dari konten para Key Opinion Leaders dan cara mereka bekerja di dalam perusahaan. Maka itu, dengan penelitian ini diharapkan peneliti bisa memahami persoalan-persoalan etika yang ada dan memberikan rekomendasi untuk mencegah adanya isu etika semakin besar di kemudian hari. 


\section{Pertanyaan Penelitian}

1. Nilai-nilai etika apa yang melekat pada influencers dalam proses pengambilan keputusan sesuai dengan teori virtue ethics?

2. Pedoman etika apa yang dapat digunakan untuk e-commerce untuk menciptakan kinerja yang baik saat menggunakan influencer?

\section{B. KAJIAN LITERATUR}

\section{E-Commerce}

Suatu tindakan penjualan atau pembelian dengan medium jaringan, komputer ataupun metode lainnya secara daring yang sudah dirancang secara spesifik untuk menerima dan melakuakan pesanan dapat menjadi penjelasan mengenai definisi dari e-commerce itu sendiri berdasarkan OECD, Organization for Economic Co-Operation and Development tahun 2019 (Badan Pusat Statistik, 2020:6). Pada survei yang dilakukan oleh snapcart pada Januari 2018, BPS mengutip bahwa ternyata ditunjukan bahwa konsumen dari $e$ commerce 65\% mayoritas adalah dari kaum wanita. Badan Pusat Statistik, 2020:16).

\section{Komunikasi Pemasaran dan Opinion Leaders}

Agar suatu perusahaan dapat mengirimkan pesan tentang penawaran produk atau jasanya, maka perusahaan memiliki media komunikasinya sendiri. Komunikasi pemasaran bertujuan untuk membantu kesadaran konsumen, mengarahkan mereka dalam pembelian atau komitmen, serta membangun sikap positif terhadap produk atau jasa yang ditawarkan (Schiffman, L.G., dan Kanuk, L.L, 2010; 281). Model komunikasinya adalah sebagai berikut pada gambar 1 dimana pertama pengirim akan mengirimkan pesan, menuju channel sebagai medianya, kemudian akan diterima oleh konsumen sesuai yang dipahaminya yang akan memberikan respons atau feedback terhadap pesan yang diterimanya.

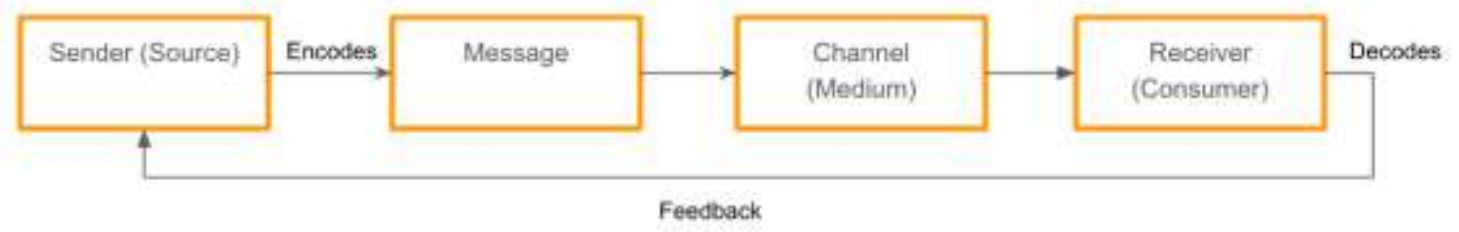

Sumber : diadaptasi dari Schiffman,L.G., dan Kanuk,L.L, 2010)

\section{Gambar 1. Model Komunikasi}

Pengirim dapat berupa sumber formal atau informal sebagai sumber dari perusahaan itu sendiri. Kelompok yang informal ini, memiliki frame of reference, atau sebuah referensi yang sesuai dengan pengikut-pengikutnya, membantu dalam penyebaran pesan ini, sering disebut juga sebagai Word of Mouth (WOM), beberapa sosiolog memberi sekelompok orang ini sebutan Opinion Leadership, yaitu sekelompok orang atau grup yang mampu memengaruhi orang lain dalam tingkah laku, perilaku, sebagai pencari pendapat atau penerima pendapat. (Schiffman, L.G., dan Kanuk, L.L, 2010:282).

\section{Etika dalam Pemasaran}

Kata etika aslinya berasal dari kata ethos, sebuah kata Yunani, yang memiliki arti "adat" atau "konvensional" (DesJardins, 2014: 14). Makna katanya secara umum dapat diartikan sebagaimana seharusnya orang hidup sesuai dengan keyakinan, atau sikap, bahkan nilai- 
nilai yang sewajarnya ada dan dalam sesuai budaya yang berlaku. Dalam bidang bisnis diartikan bahwa melakukan praktik bisnis memiliki standar sendiri-sendiri yang dapat disebut sebagai praktik etis (DesJardins, 2014: 15). Etika dalam bisnis meliputi berbagai macam aspek-aspek dalam seluruh proses bisnis, termasuk dalam konteks pemasaran.

Kaptein (2008: 980) memberikan beberapa contoh praktek bisnis tidak etis yang berkaitan dengan pemasaran, khususnya yang terkait langsung dengan pelanggan sebagai salah satu pemangku kepentingan dalam bisnis, antara lain praktek penjualan dan pemasaran yang menipu, seperti pencitraan harapan yang tidak realistis, memberikan faktur yang menyesatkan kepada pelanggan, memalsukan atau memanipulasi kualitas produk atau hasil uji aturan keselamatan.

Berdasarkan Schiffman dan Kanuk (2010: 516-525), terdapat beberapa strategi pemasaran yang berkaitan dengan promosi yang dianggap tidak etis, khususnya beberapa strategi pemasaran yang menyasar pada kerentanan manusia (atau vulnerability) dalam mencapai target bisnis perusahaan. Dalam hal ini, kelemahan manusia menjadi sumber yang dipergunakan.

Contoh pemasaran yang dilakukan tetapi tidak etis menurut Schiffman dan Kanuk adalah memberikan tekanan yang membuat calon konsumen tidak berpikir secara realistis atau menargetkan kepada orang-orang yang sudah dalam tekanan seperti penyakit berat atau kritis. Selain itu, beberapa di antara strategi-strategi tidak etis tersebut adalah penargetan eksploitatif seperti pemasaran kepada anak-anak, promosi yang terlalu agresif, penjualan obat-obatan langsung ke konsumen, hilangnya privasi konsumen, paparan iklan yang dipaksakan, dan iklan palsu atau menyesatkan. Untuk mengecek apakah sebuah teknik pemasaran masih termasuk dalam perilaku etika bisnis, DeJardins (2014: 181) memberikan beberapa kondisi yaitu:

\section{Voluntariness}

Konsumen tidak membeli karena terpaksa atau dalam keadaan tertekan, tetapi dikarenakan memang secara keinginan pribadi.

\section{Consent of Exchange}

Konsumen memiliki kesadaran penuh dan informasi lengkap mengenai barang atau jasa yang dibeli.

\section{Truly Benefited}

Konsumen benar memiliki manfaat sesuai dengan barang atau jasa yang dibeli atau ditawarkan

\section{Externalities/Override Values}

Konsumen memiliki pengetahuan yang cukup jika barang atau jasa tersebut memiliki eksternalitas atau efek samping yang patut diketahui.

\section{Virtue Ethics}

Virtue Ethics adalah studi yang mengkaji perilaku orang terhadap tindakan yang kualitas intrinsiknya membuat seseorang terpuji, unggul atau berbudi luhur. Inti dari studi ini adalah bahwa individu mungkin memiliki dua pilihan ekstrim mereka sendiri dan perlu bertindak dengan cara yang akan dianggap berbudi luhur (Mintz 1996: 827 dalam Crossan et.al, 2013: 570).

Virtue Ethics menjelaskan bahwa orang tidak bisa digambarkan sebatas baik atau buruk, benar atau salah, tetapi memberikan pemahaman yang lebih dalam, mengedepankan kepada karakter keseluruhan dari individu. Hal ini juga terkait dengan dunia bisnis, dimana orang-orang memiliki pilihan untuk menjadi serakah atau dermawan, menjadi penyayang 
atau kejam, baik manipulatif atau adil, peluang akan lebih menggambarkan ciri-ciri karakter mana yang membantu orang dalam berbisnis (Desjardins, J., 2014: 42).

Dalam artikel oleh Crossan, Mazutis, \& Seijts, Ferell et.al membuat kerangka virtue ethics yang lebih mendefinisikan bagaimana seseorang mengambil keputusan berbasis etika yang didasari kepada keunggulan karakter pribadi orang tersebut yang kemudian dikembangkan lagi oleh Crossan, et.al (Ferrell et al, 2009 dalam Crossan, et.al, 2013: 569). Hal tersebut kemudian dirangkai dalam suatu lingkaran virtue ethics dimana menganalisa perbuatan seseorang tersebut sehingga ia bisa mengambil keputusan, atas nilai apa yang mendorong seseorang itu untuk melakukan keputusan beretika atau tidak, lalu jika ada tekanan dari luar yang memengaruhi orang tersebut mengambil keputusan. Hal ini dapat dilihat seperti di gambar 2.

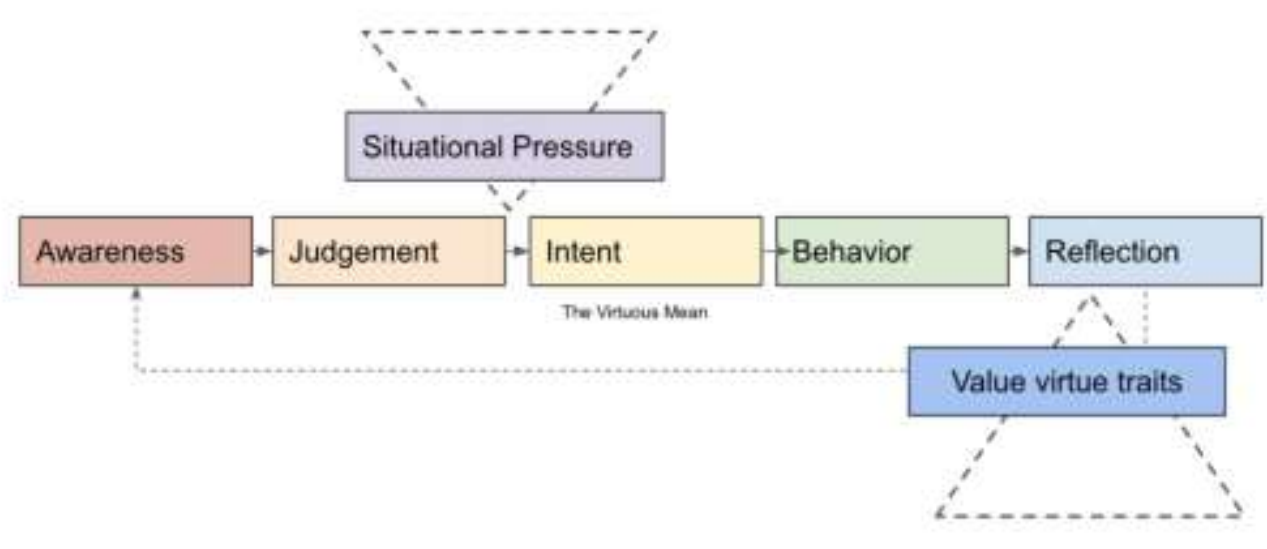

Sumber : diadaptasi dari Crossan, Mazutis, \& Seijts (2013)

Gambar 2.Etika Kebajikan (Virtue Ethics)

Berdasarkan model yang tradisional, Ethical Decision Making (EDM) atau proses pengambilan keputusan berbasis etika memiliki empat komponen proses psikologis (awareness, judgement, intent, dan behavior). Dalam model Crossan et al. (2013), proses ini dimodifikasi dengan membangun model siklus dengan lima pendekatan dimulai dari kesadaran (awareness), penilaian (judgement), niat (intent), perilaku (behavior), dan refleksi (reflection). Pada model ini, Crossan,et.al. (2013) memberikan gambaran tentang seseorang yang dihadapkan pada situasi tertentu (situational pressure), pada situasi ini kesadaran individu akan menentukan penilaian apa yang akan dia ambil.

Melalui penilaian Crossan,et.al, individu tersebut kemudian akan memiliki beberapa niat yang mengarah pada perilakunya. Hal ini akan sangat berkaitan dengan sifat-sifat kebajikan nilai yang dimilikinya. Terakhir, perilaku tersebut akan mengarahkan individu untuk memiliki refleksi, yang dikaitkan dengan nilai-nilai kebajikan (virtues), yang kemudian diharapkan dapat berdampak pada proses pengambilan keputusan di masa yang akan datang. Proses ini secara prinsip akan terus berputar sesuai dengan nilai-nilai yang mereka miliki. 
ISSN NO. (PRINI) 2598-0823, (ONLINE) 2598-2893

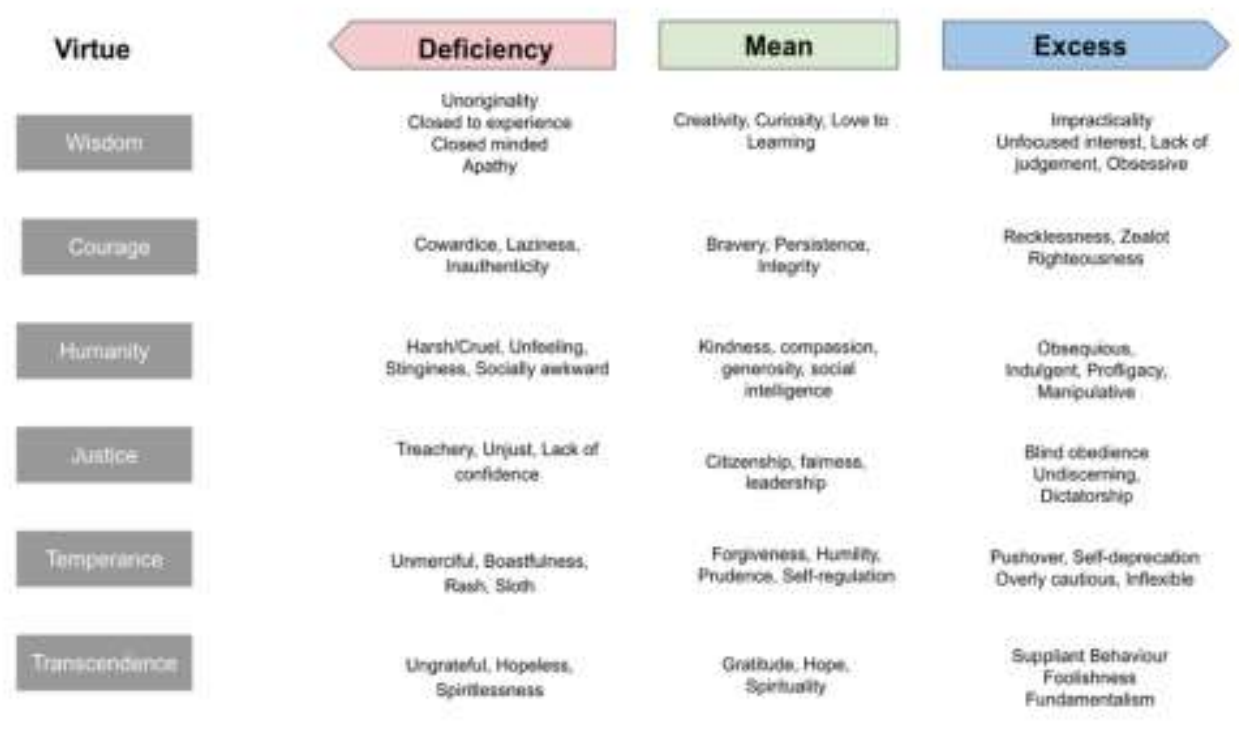

Sumber : diadaptasi dari Crossan et al. (2013)

Gambar 3. Daftar nilai-nilai pada VBO Model

Gambar diatas adalah daftar dari nilai-nilai berdasarkan virtue sesuai dengan Value Based Model (VBO). Nilai-nilai tersebut yang akan digunakan / dicocokkan sebagai dasar dari penelitian kepada para Key Opinion Leaders. Nilai-nilai apa saja yang akan memengaruhi para Key Opinion Leaders dalam membuat keputusan berbasis etika dan yang perlu ditingkatkan lagi.

\section{B. METODOLOGI PENELITIAN}

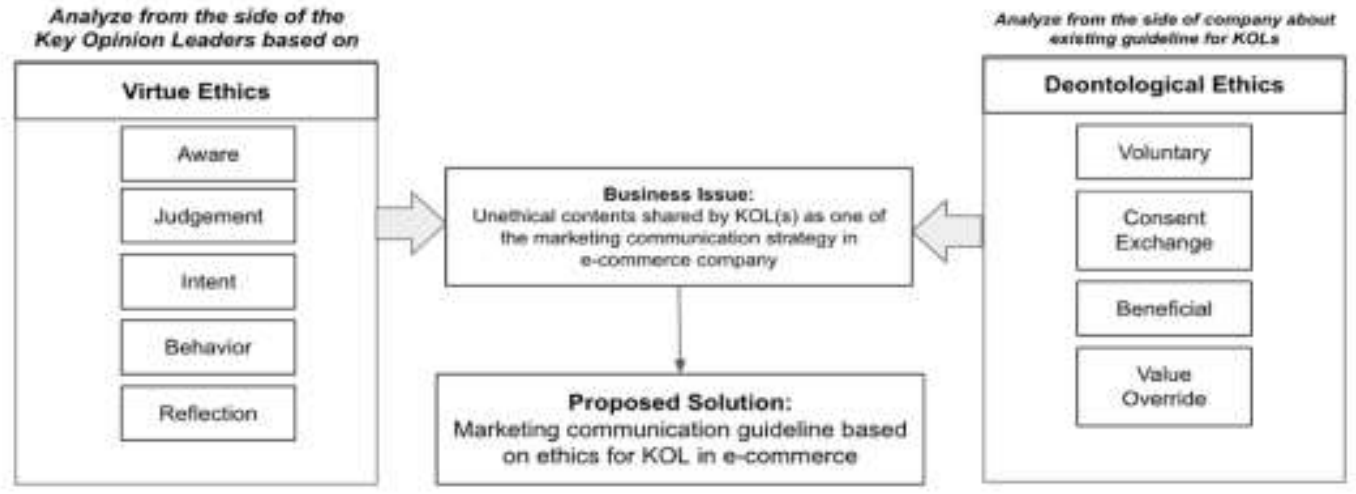

Sumber : Oleh Peneliti, 2021

Gambar 3. Metode Konsep Penelitian

Penelitian dilakukan terhadap perusahaan $\mathrm{X}$ yang berada di wilayah Jakarta Selatan, nama perusahaan dan nama responden disamarkan untuk menjaga kerahasiaan. Pertanyaan yang disusun dalam wawancara mengikuti model dari etika yaitu sebagai pada gambar 3 . 


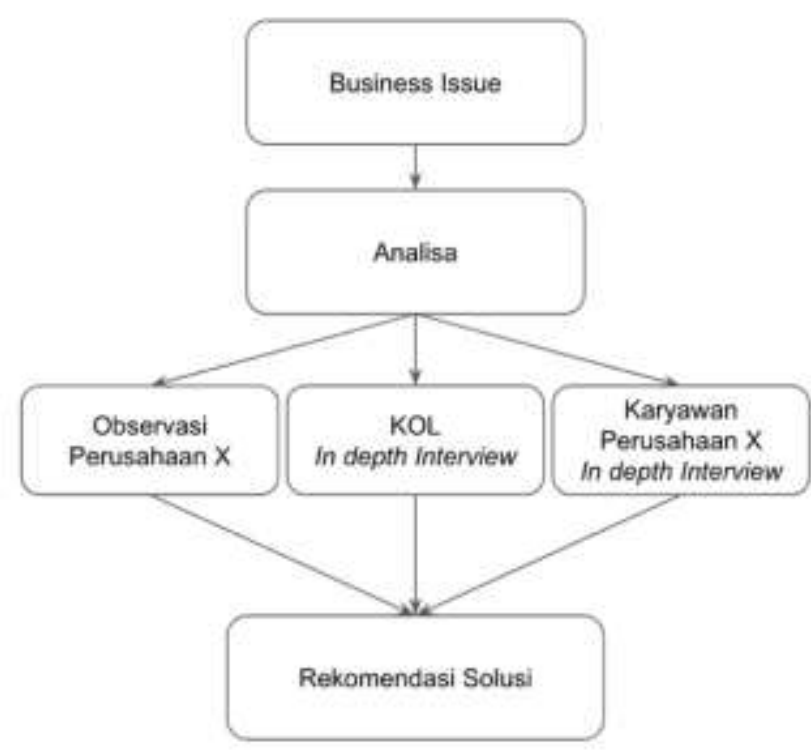

Sumber : Oleh Peneliti, 2021

Gambar 4. Proses Metode Penelitian

Riset ini menggunakan tipe problem solving, yaitu peneliti akan melakukan penelitian terkait isu bisnis yang diangkat dalam latar belakang dan perusahaan tersebut, lalu peneliti akan melakukan analisis terkait dengan isu permasalahan bisnis tersebut dengan objek dan subjek penelitian, lalu peneliti akan memberikan rekomendasi berdasarkan hasil analisis sebagai solusi yang bisa diterapkan untuk menyelesaikan isu bisnis tersebut.

\section{Subjek Penelitian}

Tabel 1. Subjek Penelitian

\begin{tabular}{|c|c|c|c|}
\hline No Interviewee & Jenis Kelamin & $\begin{array}{l}\text { Lama } \\
\text { Bekerja }\end{array}$ & Posisi \\
\hline 1 Interviewee $A$ & Perempuan & 1 tahun & $\begin{array}{l}\text { Karyawan Tetap } \\
\text { Perusahaan X }\end{array}$ \\
\hline 2 Interviewee B & Perempuan & 2 tahun & $\begin{array}{l}\text { Karyawan Tetap } \\
\text { Perusahaan X }\end{array}$ \\
\hline 3 Interviewee C & Perempuan & 1 tahun & $\begin{array}{l}\text { KOL Specialist Perusahaan } \\
\mathrm{Y}\end{array}$ \\
\hline 3 Interviewee 1 & Perempuan & 1 tahun & KOL Perusahaan X \\
\hline 4 Interviewee 2 & Perempuan & 4 bulan & KOL Perusahaan X \\
\hline 5 Interviewee 3 & Perempuan & 8 bulan & KOL Perusahaan X \\
\hline
\end{tabular}

Sumber: Peneliti, 2021 
- Perusahaan X

- Perusahaan $X$ adalah salah satu perusahaan e-commerce di Indonesia yang telah berdiri lebih dari 5 tahun. Perusahaan ini menjadi salah satu pemain bisnis yang berhasil di industri e-commerce ini di Indonesia. Peneliti melakukan penelitian terhadap perusahan $\mathrm{X}$ selama 3.5 bulan dengan Teknik observasi.

- Key Opinion Leaders

- Key Opinion Leaders yang diwawancara berjumlah tiga orang, terdiri dari perwakilan KOL yang menunjukan performa yang baik pada perusahaan $\mathrm{X}$. Sesuai data pada tanggal 3 Maret 2021, KOL 1 memiliki 18.400 pengikut di Instagram, KOL 2 memiliki 52.700 pengikut di Instagram, dan KOL 3 memiliki akun terverifikasi di Instagram yang sudah menjadi influencer penuh waktu dengan 123.000 pengikut Instagram. Alasan pemilihan $3 \mathrm{KOL}$ ini adalah karena telah menunjukan performa yang baik dan ketekunannya, sehingga dapat lebih mendalami dalam proses pengambilan keputusan sebagai seorang KOL.

- Karyawan Perusahaan X

- Subjek penelitian satu lagi adalah 2 orang dari perusahaan $X$ dan 1 orang perusahaan $\mathrm{Y} .2$ orang perusahaan $\mathrm{X}$ ini karyawan tetap yang sudah bekerja minimal 1 tahun di perusahaan tersebut dan fokus bekerja di divisi yang mengurus KOL. Satu orang dari perusahaan $Y$ adalah seorang KOL Specialist yang bekerja di perusahaan sebagai platform influencer, yaitu yang menghubungkan para influencer dengan brand yang membutuhkan.

- Teknik yang digunakan adalah wawancara mendalam atau in-depth interview. Data yang didapatkan dari perusahaan $X$ diharapkan dapat membantu mendalami tata cara atau pedoman yang sudah ada di perusahaan tersebut untuk para $\mathrm{KOL}$, lalu dari perusahaan $\mathrm{Y}$ sebagai perusahaan yang fokus kepada influencer, diharapkan mendapatkan pembelajaran supaya tata cara yang direkomendasikan tidak hanya etikal, namun bisa diterima oleh para KOL dan bisa berperforma baik dalam strategi pemasaran.

\section{HASIL DAN PEMBAHASAN}

\section{Analisis KOL sesuai Virtue Ethics}

Berdasarkan hasil analisis terhadap Value Based Model dari Crossan, et al., (2013), sebagian besar KOL mengetahui tentang apa yang boleh dan tidak boleh dilakukan dari konten influencer, terutama KOL yang berkinerja baik. Ketiga KOL ini juga menyatakan bahwa mereka juga tidak setuju dengan ulasan yang tidak jujur atau ulasan yang ambigu. Hal ini menunjukan bahwa sebenarnya tingkat kesadaran atau awareness sebagai KOL sudah semaklumnya para KOL ini mengerti. Hal ini juga dikuatkan oleh para karyawan yang menyatakan bahwa salah satu syarat menjadi KOL yang dikontrak adalah harus minimal 10,000 followers dalam Instagram atau Tiktok, sehingga sudah seharusnya para KOL mampu menempatkan diri dan memiliki kesadaran yang baik sebagai seorang KOL.

Namun berdasarkan hasil observasi, tidak semua KOL memahami mengenai perilaku etika dan tidak etika, sehingga masih ditemukan konten-konten yang tidak orisinil. Hal ini berkaitan erat dengan kekurangan (deficiency) pada value wisdom, yaitu tidak kuatir menjadi tidak asli di media sosial dan mengambil karya orang lain. Sehingga pada langkah 
judgement nilai tersebut sangat terlihat sampai pada pengambilan keputusan yang menyebabkan adanya beberapa konten yang tidak orisinil.

Selanjutnya, pada tahap intent, alasan interviewee menjadi influencer adalah pertama karena orientasi uang sebagai pendapatan sampingan dan juga untuk membantu brand. Bekerja menjadi influencer dapat mereka lakukan secara pekerja lepas, sehingga hal ini menjadi nilai lebih bagi mereka untuk bisa tetap mencari pekerjaan penuh waktu seperti di kantor, tetapi memiliki pendapatan lain sebagai tambahan. Sehingga, pada tahap ini nilai yang paling kuat yang ada di KOL adalah humanity, yaitu kemampuannya untuk mau bekerja dengan baik, bagi brand yang dipromosikan, perusahaan tempat mereka dikontrak, juga bagi para followers mereka.

Pada tahap penentuan perilaku (behavior), perilaku yang berhubungan dengan influencer adalah konsistensi dan kreativitas. Kemampuan para KOL untuk tetap berkarya secara kreatif harus diikuti dengan ketekunannya yang konsisten untuk membuat konten. Sehingga ditemukan perbedaan bagi para KOL yang kekurangan kedua karakter ini, KOL yang kurang rajin akhirnya kurang berkarya dan berpengaruh pada performa yang buruk.

Pada tahap reflect sikap yang mencerminkan perilaku tersebut adalah sikap profesionalisme, integritas, kejujuran, dan orisinalitas. Nilai-nilai transcendence seperti rasa bersyukur dan gratitude sangat kuat disini, dimana KOL yang merasa puas dengan pencapaian dan pembayaran yang mereka dapatkan, bisa mencerminkan pula perilaku yang baik terhadap para karyawan yang bekerja bersama para KOL. Namun jika mereka tidak bersyukur akan pendapatannya, para KOL kemudian bisa berperilaku tidak etis seperti melakukan fraud atau penipuan supaya mendapatkan pembayaran yang lebih tetapi tidak jujur. Secara singkatnya, hasil analisa berdasarkan virtue ethics dapat dilihat pada gambar 4.

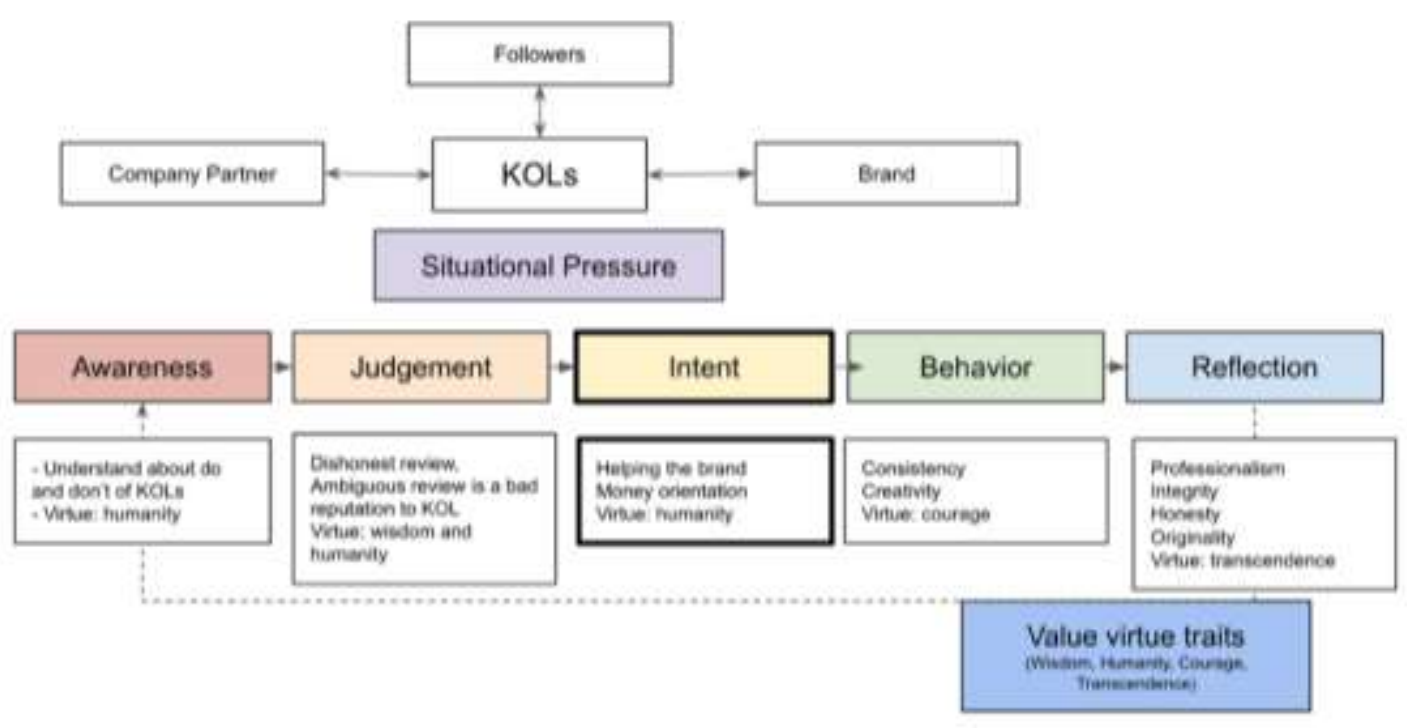

Sumber : Oleh Peneliti, 2021

Gambar 4. Hasil Penelitian Pembuatan Keputusan di Kalangan KOL Perusahaan X 
Selain menganalisa nilai, gambar 4 juga menjelaskan mengenai tekanan yang dialami oleh KOL. Menjadi KOL tidak terlepas dari tekanan situasional. Para KOL sangat berkaitan erat dengan perusahaan tempat mereka bekerja, brand yang dipromosikan, dan sangat dekat dengan pengikut mereka. Ketiga hal ini yang menjadi sumber tekanan bagi para KOL. Menurut wawancara, mereka merasa harus memuaskan ketiga hal ini, para pengikut yang harus senang dengan konten yang dibagikan, brand yang dipromosikan harus bisa mendapatkan engagement yang tinggi, dan perusahaan juga meminta KOL untuk terus menghasilkan konten dengan performa yang baik. Pada perusahaan $\mathrm{X}$, performa para $\mathrm{KOL}$ dihitung berdasarkan penjualan yang berhasil mereka lakukan dari konten yang mereka bagikan. Sehingga, berdasarkan analisa dapat juga disimpulkan pada tabel 2 yang sebaiknya ditingkatkan dan dapat dipertahankan oleh para KOL:

\begin{tabular}{llllll} 
& \multicolumn{4}{l}{ Tabel 2. Analisis Nilai-Nilai KOL sesuai dengan Virtue Ethics } \\
& Awareness & Judgement & Intent & Behavior & Reflection \\
\hline Wisdom & Perlu & Perlu & Perlu & Perlu & Perlu \\
& ditingkatkan & ditingkatkan & ditingkatkan & ditingkatkan & ditingkatkan \\
\hline Courage & Perlu & Perlu & Perlu & Perlu & Perlu \\
& ditingkatkan & ditingkatkan & dipertahankan & dipertahankan & ditingkatkan \\
\hline Humanity & Perlu & Perlu & Perlu & Perlu & Perlu \\
& dipertahankan & dipertahankan & ditingkatkan & ditingkatkan & ditingkatkan \\
\hline Justice & Perlu & Perlu & Perlu & Perlu & Perlu \\
& ditingkatkan & ditingkatkan & ditingkatkan & ditingkatkan & ditingkatkan \\
\hline Temperance & Perlu & Perlu & Perlu & Perlu & Perlu \\
& ditingkatkan & ditingkatkan & ditingkatkan & ditingkatkan & ditingkatkan \\
\hline Transcendence & Perlu & Perlu & Perlu & Perlu & Perlu \\
& ditingkatkan & ditingkatkan & ditingkatkan & ditingkatkan & dipertahankan
\end{tabular}

Sumber: Analisis Peneliti

\section{Analisis Pedoman sesuai Etika Pemasaran}

Berdasarkan analisis pada pedoman yang sudah ada, ternyata masih banyak aspek etika pemasaran yang belum tertera pada pedoman tersebut. Pedoman yang tersedia belum secara eksplisit menjelaskan tentang empat pemasaran etis untuk KOL di e-commerce. Ini mungkin menjadi alasan ditemukannya kasus ada beberapa konten yang dianggap tidak etis dibagikan oleh KOL. Berdasarkan hasil data observasi, guideline yang sudah ada di perusahaan $\mathrm{X}$ dan diberikan oleh perusahaan terhadap $\mathrm{KOL}$ adalah sebagai berikut:

\begin{tabular}{|c|c|}
\hline Voluntariness & $\begin{array}{l}\text { - KOL tidak diperbolehkan mencemarkan nama baik ras, } \\
\text { jenis kelamin, etnis, usia, kebangsaan, agama, orientasi } \\
\text { seksual } \\
\text { - KOL tidak boleh memaksa seseorang untuk melakukan } \\
\text { sesuatu yang berbahaya, terutama untuk anak-anak }\end{array}$ \\
\hline Consent Exchange & $\begin{array}{l}\text { - Segala bentuk kekerasan dilarang } \\
\text { - KOL tidak diperbolehkan melakukan pencemaran nama } \\
\text { baik }\end{array}$ \\
\hline Truly Benefit & $\begin{array}{l}\text { - Produk dan layanan ilegal dilarang untuk dijadikan } \\
\text { konten yang telah direview }\end{array}$ \\
\hline $\begin{array}{l}\text { Value } \\
\text { Override/Extern }\end{array}$ & $\begin{array}{l}\text { - } \mathrm{KOL} \text { tidak diperbolehkan untuk menyebut nama } \\
\text { perusahaan pesaing dalam konten KOL } \\
\text { - KOL tidak boleh memberikan konten eksolisit tentana }\end{array}$ \\
\hline
\end{tabular}


pornografi atau konten eksplisit terlarang lainnya.

\section{Sumber: Analisis Peneliti}

Dalam pedoman tersebut, perusahaan $X$ sudah memiliki beberapa pedoman yang bisa dimasukan pada bagiann etika pemasaran, namun belum begitu lengkap dan detil. Akibat dari kurangnya tata cara ini adalah ditemukan beberapa konten yang seharusnya dan sebaiknya tidak dibagikan di platform tersebut. Contohnya adalah ditemukan konten promosi minuman bir yang tidak diberikan penjelasan lengkap bahwa seharusnya minuman tersebut hanya diperbolehkan untuk usia 21 tahun ke atas.

\section{Rekomendasi Solusi Pedoman Komunikasi Pemasaran}

Melihat bahwa platform ini terbuka luas di aplikasi e-commerce tersebut, semua usia yang menggunakan aplikasi ini dapat melihat dan membelinya pula. Sehingga berdasarkan penelitian yang dilakukan, tambahan pedoman konten tata-cara yang bisa dikomunikasikan kepada para KOL dapat diusulkan berdasarkan etika deontology pemasaran dan juga sesuai dengan peraturan komunikasi pemasaran yang diterapkan oleh perusahaan $\mathrm{X}$ adalah sebagai berikut:

\section{Voluntariness}

- Key Opinion Leader (KOL) tidak boleh memberikan tekanan apa pun kepada calon konsumen seperti: memberikan fakta tidak resmi yang mengerikan atau menakutkan yang dapat membuat pelanggan mungkin memiliki penilaian yang bias; memberikan pernyataan palsu tentang pesaing lain atau melemahkan pihak pesaing

- $\quad \mathrm{KOL}$ harus mengelola konten mereka untuk orang-orang yang cukup dewasa dalam membuat keputusan, yaitu kepada konsumen yang sebagian besar berusia di atas 17 tahun.

\section{Consent Exchange}

- $\mathrm{KOL}$ harus menghargai data pribadi konsumen. KOL tidak diperbolehkan menanyakan informasi pribadi dan privat apapun kepada konsumen di depan umum dengan alasan apapun. Informasi pribadi apa pun hanya perlu dibagikan dengan persetujuan dan di platform yang aman. Informasi pribadi termasuk Nomor ID (KTP, NPWP), nomor telepon, dll.

\section{Truly Benefit}

- KOL tidak boleh membesar-besarkan konten atau melebih-lebihkan konten yang dibuatnya.

- $\quad \mathrm{KOL}$ harus memberikan ulasan yang jujur dan tidak diperbolehkan berbohong tentang manfaat produk

- $\quad \mathrm{KOL}$ tidak boleh menjadi bagian dari masalah politik atau memasukan masalah politik dalam konten promosi

- KOL tidak boleh mendorong atau memaksa pelanggan mereka untuk melakukan perilaku kriminal

- KOL dalam kontrak hanya boleh membagikan konten asli dan jika menggunakan konten lain, influencer harus menuliskan pembuat konten asli tersebut.

\section{Value Override/Externalities}


- $\quad \mathrm{KOL}$ harus menyebutkan jika produk yang diulas memiliki nilai efek samping lain (misalnya: jika produk perawatan kulit hanya berfungsi untuk jenis kulit tertentu dan akan berbaaya jika tidak sesuai dengan jenis lainnya.)

- KOL harus menulis informasi lengkap atau disclaimer jika konten yang dibagikan adalah untuk usia atau kondisi tertentu menurut hukum (misalnya: bir hanya untuk $21+$ )

- Konten yang dibagikan oleh para KOL sebaiknya adalah produk atau jasa yang sudah terbukti aman digunakan, bisa dilihat dengan terdaftar resmi di Indonesia atau internasional.

- Jika produk belum terdaftar secara resmi, influencer harus menyebutkannya dengan jelas sehingga pelanggan sehingga para calon konsumen sadar dan memahami risikonya

- Vape, rokok, senjata, termasuk senjata tajam tidak boleh dibagikan dalam konten (ini juga sesuai acuan pada peraturan baru Instagram (Detik, 2019))

- Kontrasepsi, aborsi ilegal, pil ilegal dilarang digunakan sebagai produk review dalam konten KOL. (Konten seperti ini bukan menjadi ranah oleh KOL)

- KOL tidak boleh memberikan konten yang berbicara buruk tentang perusahaan pesaing lain. KOL juga harus membagikan konten secara etika dan menghormati para pesaing dengan baik dalam bisnis.

- KOL tidak boleh mempromosikan penjualan makhluk hidup apa pun.

Berdasarkan pedoman tersebut, tentunya akan ada manfaat dan resiko yang dimiliki pada pedoman tersebut, sehingga untuk mengatasi resiko tersebut, tabel 4 adalah analisis rekomendasi pada pedoman tersebut. Analisis ini berguna untuk memperhatikan strategi yang digunakan dalam menerapkan pedoman kepada para KOL. Dikarenakan hal ini adalah hal yang termasuk baru kepada pada kalangan KOL, perusahaan juga harus siap dalam proses adaptasi yang akan dilakukan pada KOL.

Tabel 4. Analisis Rekomendasi Pedoman Komunikasi Pemasaran Perusahaan X

Manfaat - Jika manajemen setuju untuk mengubah tata cara yang ada, akan berguna untuk KOL yang akan bergabung.

- Pedoman akan berguna bagi KOL jika dilakukan akuisisi setiap bulan bukan per minggu,

- Pedoman dapat digunakan untuk jangka waktu yang panjang.

Resiko - KOL yang sudah bergabung sebelum adanya pedoman baru, tidak akan mengetahui pedoman barunya, sehingga butuh penyesuaian dan acara sosialisasi sendiri.

- Akan membutuhkan waktu yang cukup Panjang sampai persetujuan didapatkan pada pihak manajemen.

- Jika dilakukan pada proses onboarding, diperlukan waktu lebih banyak disbanding biasanya.

- Beberapa KOL mungkin memandangnya sebagai hal yang sulit dan membosankan, sehingga perlu diberikan penjelasan mengapa hal ini penting.

Mitigasi $\quad$ - KOL yang sudah mengikuti program ini dapat dibuatkan acara baru atau resiko sesi khusus yang hanya menjelaskan mengenai pedoman baru.

- Penjelasan pedoman bisa dilakukan dengan cara yang akrab dan hangat dibandingkan kaku.

- Perlu dijelaskan juga alas an pentingnya pedoman ini. 
Sumber: Analisis Pribadi Peneliti, 2021

\section{E. KESIMPULAN}

\section{Kesimpulan}

Para Influencers sebagai KOL memiliki nilai-nilai yang kuat yang mendorong mereka dalam bekerja sebagai pembuat konten dan influencer. Nilai-nilai tersebut antara lain terkait dengan integritas, kreativitas, dan kearifan. Influencer harus memiliki kreativitas yang baik dalam membuat konten (yaitu sesuatu yang bernilai praktis atau ada gunanya dan origina) dan manajemen waktu yang baik. Berdasarkan analisis model virtue ethics, ditemukan bahwa nilai terkuat (yaitu nilai yang sudah berpotensi untuk diaplikasikan) yang menjadi dasar seorang influencer sebagai KOL membuat keputusan yaitu nilai-nilai kemanusiaan, kebijaksanaan, keberanian, dan transendensi. Nilai-nilai ini dapat membantu proses keputusan KOLs, apakah akan berperilaku etika atau tidak.

Berdasarkan hasil analisis, salah satu cara yang perusahaan bisa lakukan untuk mencegah adanya tindakan tidak etis atau konten tidak etis yang dibagikan adalah dengan membuat pedoman yang terbuka dan dapat dipahami oleh para KOL. Pedoman yang dimaksud bukan hanya yang terkait dengan teknis pemasaran, melainkan juga pedoman yang terkait dengan etika pemasaran. Setelah melalui proses analisis, peneliti memberikan usulan solusi bisnis strategi komunikasi pemasaran berbasis etika dalam berupa pedoman bagi KOL di e-commerce yang bisa diterapkan pada perusahaan tersebut. Pedoman ini juga secara umum bisa diterapkan pada perusahaan manapun dalam industri e-commerce yang bekerja dengan para influencers sebagai Key Opinion Leaders.

\section{Saran dan Penelitian Selanjutnya}

1. Berdasarkan penelitian, ditemukan bahwa banyak KOL sudah digunakan oleh perusahaan, namun kurang diperhatikan dalam sisi etika. Disarankan agar perusahaan dapat memberikan perhatian dalam sisi etika khususnya pemasaran dikarenakan KOL akan menjadi "wajah" yang mewakili perusahaan.

2. Dari segi proses penelitian, penelitian ini terbatas dari segi waktu yang terhitung cukup singkat. Sehingga untuk penelitian kedepannya, dapat disarankan supaya memperluas penelitian terhadap isu etika pemasaran dan efeknya terhadap pembelian, atau hal-hal lainnya seperti tingkat kepercayaan publik terhadap produk atau brand.

3. Pada penelitian selanjutnya, dapat juga konsep penelitian ini diterapkan pada industri lain selain e-commerce. Dengan berkembangnya era digital, semakin banyak juga perusahaan di industri lain yang menggunakan influencer marketing, dikarenakan dengan tekanan dan demand yang berbeda, mungkin juga dapat memberikan hasil penemuan yang berbeda terhadap para KOL di berbeda industri. 


\section{DAFTAR PUSTAKA}

Astuti, R.L.M.B, 2016. Pengaruh Promosi Online dan Celebrity Endorser terhadap Minat Beli Konsumen Tas Online Shop Fani House. E-Journal Universitas Diponegoro tahun 2016.2 https://ejournal3.undip.ac.id/index.php/interaksionline/article/view/14474/14004

Badan Pusat Statistik (BPS). Statistik E-Commerce 2020. Retrieved from: https://www.bps.go.id/publication/2020/12/24/2548417ddc6dab8247553124/statisti k-e-commerce-2020.html

Buletin APJII Edisi 23 April 2018. Downloaded from: https://apjii.or.id/downfile/file/BULETINAPJIIEDISI23April2018.pdf. Accessed on 29 March 2021.

Crossan, M., Mazutis, D., Seijts, G. 2013. In Search of Virtue: The Role of Virtues, Values and Character Strengths in Ethical Decision Making. Journal of Business Ethics 2013113:567-581. DOI:10.1007/s10551-013-1680-8

DesJardins, J. 2014. An Introduction to Business Ethics, Fifth Edition. McGraw Hill: Singapore.

Detik. Influencer Dilarang Promosikan Vape. Obtained from: https://inet.detik.com/cyberlife/d-4829661/influencer-instagram-dilarangpromosikan-vape. Accesed on 2 April 2021.

DIGITAL 2020: INDONESIA by Hootsuite. Obtaned from: https://datareportal.com/reports/digital-2020-indonesia. Accessed on 5 March 2021.

Kaptein, M. 2008. Developing a Measure of Unethical Behavior in the Workplace: A Stakeholder Perspective. Journal of Management 2008 34:978.

Lesmana, R. (2019). Analisis Strategi Bersaing PT Dwi Perkasa Mobiltama Pamulang untuk Meningkatkan Penjualan. JIMF (Jurnal IImiah Manajemen Forkamma), 3(1)

Lesmana, R., Habiyah, W., \& Nabila, N. I. (2020). Peran Kepuasan Wisatawan Terhadap Loyalitas Wisatawan Pada Objek Wisata Kepulauan Seribu Jakarta. JIMF (Jurnal IImiah Manajemen Forkamma), 3(2).

Lesmana, R., Sunardi, N., Hastono, H., \& Widodo, A. S. (2021). Perceived Quality Membentuk Customer Loyalty via Brand Equity pada Pengguna Smartphone Merek Xiaomi di Tangerang Selatan. Jurnal Pemasaran Kompetitif, 4(2), 157-167.

Lesmana, R., Sutarman, A., \& Sunardi, N. Building A Customer Loyalty Through Service Quality Mediated by Customer Satisfaction.

Maulana, I., Manulang, J.M, Salsabila, O. 2020. Pengaruh Social Media Influencer terhadap Perilaku Konsumtif di Era Ekonomi Digital. Majalah IImiah Bijak Vol 17, No.1, Maret 2020, pp 28-34. https://ojs.stiami.ac.id/index.php/bijak/article/view/823

Nielsen Insight 2019 Article. Obtained from: https://www.nielsen.com/ie/en/insights/article/2019/measure-for-measure-like-it-ornot-influencer-marketing-is-changing/. Accessed on 8 March 2021

Nielsen TapInfluence 2016. Sales Effect Study: Influencer Marketing. Obtained from:https://cdn2.hubspot.net/hubfs/1882019/TapInfluence/Resources/1009\%20\%20Nielsen_Study_Case_Study.pdf. Accessed on 9 March 2021. 
Schiffman, L.G and Kanuk, L.L. 2010. Consumer Behavior, tenth Edition. Pearson:New Jersey

Statista Digital Markets eCommerce in Indonesia. Obtained from: https://www.statista.com/outlook/dmo/ecommerce/indonesia. Accessed on 10 March 2021.

Sunardi, N., \& Lesmana, R. (2020). Konsep Icepower (Wiramadu) sebagai Solusi Wirausaha menuju Desa Sejahtra Mandiri (DMS) pada Masa Pandemi Covid19. JIMF (Jurnal IImiah Manajemen Forkamma), 4(1).

Techno. Pertumbuhan E-Commerce Tahun Ini Meningkat Tajam di Indonesia. Anjasman Situmorang. Obtained from: https://techno.okezone.com/read/2020/11/04/16/2304173/pertumbuhan-ecommerce-tahun-ini-meningkat-tajam-di-indonesia. Accessed on 19 March 2021. 